\title{
Strategies to Reduce Water Footprint in Palm Oil Production: A Case of PTP Mitra Ogan, Baturaja, South Sumatra
}

\author{
Herda Sabriyah Dara Kospa ${ }^{1,}$, Kris R.D. Lulofs ${ }^{2}$, Chay Asdak ${ }^{3}$ and Supli E. Rahim ${ }^{4}$ \\ ${ }^{1}$ Urban and Regional Planning Department, Indo Global Mandiri University, Palembang, 30129, \\ Indonesia \\ ${ }^{2}$ Master of Environmental and Energy Management, University of Twente, Leeuwarden, The \\ Netherlands \\ ${ }^{3}$ Master of Environmental Science, University of Padjadjaran, Bandung, 40132, Indonesia \\ ${ }^{4}$ University of Palembang, Palembang, South Sumatra, 30139, Indonesia
}

\begin{abstract}
The massive expansion of palm oil industry in Indonesia has triggered environmental issues including water-related problems which have become an important concern. Regarding the issues, sustainable practice standard has been set up as a requirement for palm oil to enter global market. Inevitably, water consumption in this sector is very crucial to be analyzed. One of the methods that can be used as a tool for sustainable appropriation of fresh water resources is water footprint analysis. The primary aim of this study was to formulate the strategies to reduce the water footprint in the palm oil production based on the best practice criteria. Both quantitative and qualitative research was conducted to get the value blue water (volume of surface or groundwater evaporated) and grey water (dilution volume to dilute pollutants according to agreed water quality standards). The values of water footprint in palm oil production obtained were used to represent the existing water use and were utilized as the basis for formulating strategies in reducing water use in the palm oil milling processes which was compared with the best practice criteria. The result showed that the blue water of CPO was $109.6 \mathrm{~m}^{3} /$ ton and the grey water was $537.7 \mathrm{~m}^{3} /$ ton, while the blue water of palm kernel was $62,4 \mathrm{~m}^{3} /$ ton and grey water was $306,2 \mathrm{~m}^{3} /$ ton. The value indicated that there was an inefficient use of water in the production of palm oil. The use of steam accumulator has been proposed to reduce the use of blue water by optimizing the steam supply. Besides, the reuse of water from fat-pit pond for pressing purposes, or recovery of condensate water as dilution water in the press unit which will affect the amount of wastewater discharged can be done as the strategies in reducing both blue and grey water, as well as reuse of cooling water turbines.
\end{abstract}

\footnotetext{
*Corresponding Author: darabantet@rocketmail.com
} 


\section{Introduction}

Nowadays, palm oil is a strategic sector in Indonesia because the trend of its export in the global market is increasingly higher, reaching 23.5 million tons per year (RSPO, 2013). The palm oil industry in Indonesia has been developing rapidly. It was twice higher from 4.2 million ha in 2000 to be 8.0 million ha in 2010 .

As one of the key elements of Indonesian economic development, the development of palm oil sector is predictably higher. It is because the Government of Indonesia has targeted to export Crude Palm Oil (CPO) at 52 million tons in 2020. Consequently, the oil palm plantation in Indonesia was projected to reach 13 hectares by 2020.

In realizing the target, all stakeholders, including companies should ensure that the palm oil industry is sustainably organized. It is because sustainable practices of palm oil industry become one of the requirements for a palm oil industry to enter the global market. In Indonesia, however, palm oil sector is facing sustainability issues due to the standards set up by RSPO. The issues include deforestation, loss of biodiversity and habitats, soil erosion, air pollution (GHG emissions), water-related problems, and social conflicts (WWF, 2012).

Among those issues, water-related problems have become an important concern. In plantation, for instance, it needs relatively high water use. According to Bergert (2000), after 11 years from plantation, palm trees with a population of 150 trees/ ha require annual rainfall of $2000 \mathrm{~mm}$ which is evenly distributed throughout the year. During the dry period with a relatively low rainfall, the freshwater consumption will be increasingly higher.

The aforementioned condition potentially causes conflicts in water utilization with other sectors, especially in dry season. For instance, villagers in Central Kalimantan and other provinces in Indonesia living nearby palm oil plantations faced water problems because of the palm oil plantation activities (SEI, 2012). The problems include reduced water debit and diverted water flow due to the constructions of channels and dams developed for the palm oil irrigation.

Meanwhile, in mills, large amount of water is also used for the palm fruit extraction. As much as $50 \%$ of water used in the extraction process becomes palm oil mill effluents (POME). From 1 ton of CPO, 5 to 7.5 tons of water in the form of POME is produced (Muyibi et al., 2014). If the effluent is directly discharged to the stream, it can cause freshwater pollution, affect the people and downstream biodiversity (WWF, 2012).

Those impacts indicate the urgency of applying sustainable water resource management in palm oil industry, which takes the efficiency and the renewability of sources into account. One of the methods that can be used as a tool for sustainable appropriation of freshwater resources is water footprint analysis. According to Hoekstra et al. (2011), water footprint can be used as a communication tool between stakeholders in better understanding on how water management can support social, economic and environmental outcomes. (Chapaign \& Tickner, 2012). For companies, the results of water footprint in their activities will provide insight, information and knowledge to consider the strategies to reduce the use of water. In this case, reducing water can give benefits for companies and for environment in general. Water reduction benefits for the companies include saving on water and sewage disposal costs, saving energy costs (through reducing appliance and hot water use) and enhancing the company reputation by being proactive in protecting environment. Meanwhile, for environment, the benefits include conserving groundwater and protecting surface water from pollution (Sappi, 2012).

Water footprint analysis is geographically, technologically, and temporally dependent. There are many studies related to the water footprint in palm oil sector throughout the world. In Indonesia, however, there is no sufficient detailed water footprint information in that sector. Hence, this research was conducted to investigate water footprint of palm oil 
production based on the case of PTP Mitra Ogan in South Sumatra, Indonesia. The primary aim of this study is to formulate the strategies to reduce the water footprint in the palm oil production based on the best practice criteria.

\section{Methods and data}

The unit of analysis use was PTP Mitra Ogan in Peninjauan District, Ogan Komering Ulu Regency, South Sumatra, Indonesia. It was one of the largest plantation companies in the South Sumatera whose land is about $65.678,95$ ha in 2013. This company had two processing mills and had developed an integrated palm oil production from cultivation to processing CPO since 1988 at a processing capacity of each 30 tons per hour. This study identified the nucleus plantation area of 655,64 ha.

\subsection{Palm Oil Production}

The stages of palm oil production include cultivation of oil palm and palm oil milling process. The processes in the mill consists of several steps, namely transportation of oil palm fruits (known as fresh fruit bunches, FFB), reception of FFB in the mill, FFB processing, waste treatment, and waste reuse.

Water is very important in the activities of a palm oil mill. It plays a role as the feed for boiler in generating power and for product treatment (Naibaho, 1996). Water used for the boiler in producing steam is equal to 0.903 tons of FFB or $2.77 \mathrm{~m}^{3} /$ ton of production.

Besides as the feed for boiler, water is also used in two hot water tanks which functions to supply water to some production machines, i.e. one machine located at the press station press and other machines in the clarification station. The stages that involve water in the palm oil production machines are illustrated in Figure 1.

In addition, water is also used in the purification process in the clarification station. The use of water in this station is very important because the purification process will produce a liquid at a desire quality level. A process of refining palm oil into CPO is intended to eliminate the water content in it reaching $0.2 \%$, so a good quality of CPO is obtained.

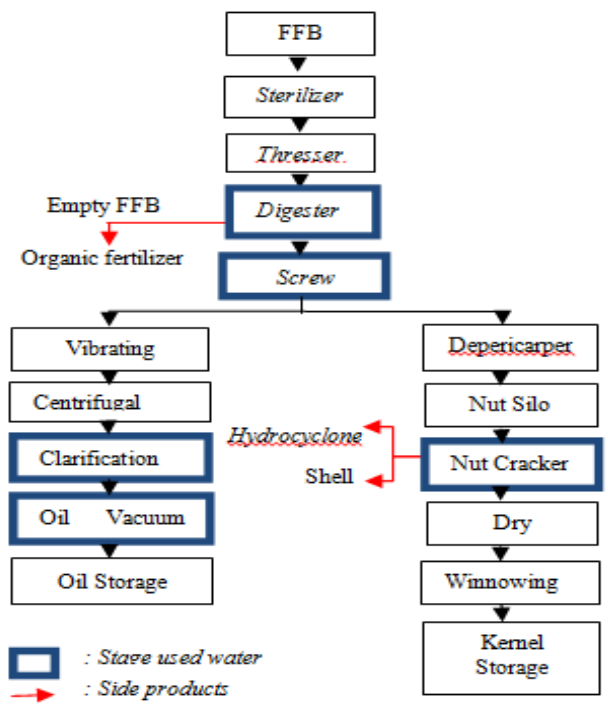

Fig. 1. CPO and Kernel Processing 
In the clarification station, the water is conducted to the hot water tank and to the pump of vacuum drier for further processing. Water in the hot water tank will then be used by the machines in the refining process. The flow of water use in the clarification station is illustrated in Figure 2.

The process of dilution required in the refining process aims to separate oil efficiently and to obtain the quality palm oil. The amount of water recommended is proportional to the amount of oil contained in the liquid. The amount of water required in the process of purification is $0.114 \mathrm{~m}^{3} /$ ton of FFB.

In addition, the use of water in the processing of palm oil also occurs in the kernel station at the machine of clay baths (separation of seeds). This separation is based on differences in the density between the kernel ( $\left.{ }^{\rho}=1.07 \mathrm{~kg} / \mathrm{m}^{3}\right)$ and shell $\left({ }^{\rho}=1.3 \mathrm{~kg} / \mathrm{m}^{3}\right)$. The mixture between the kernel and the shell is mixed with the liquid clay ( $\rho=1.2 \mathrm{~kg} / \mathrm{m}^{3}$ ) that is free of sand and calcium carbonate $\left(\mathrm{CaCO}_{3}\right)$, so that the kernel will be floating and shells will be sinking. This process is performed in a conical tank equipped with a pump to circulate the liquid clay. The addition of water in this process is as much as $0.012 \mathrm{~m}^{3} /$ ton of FFB which is done twice by mixing water and $\mathrm{CaCO}_{3}$.

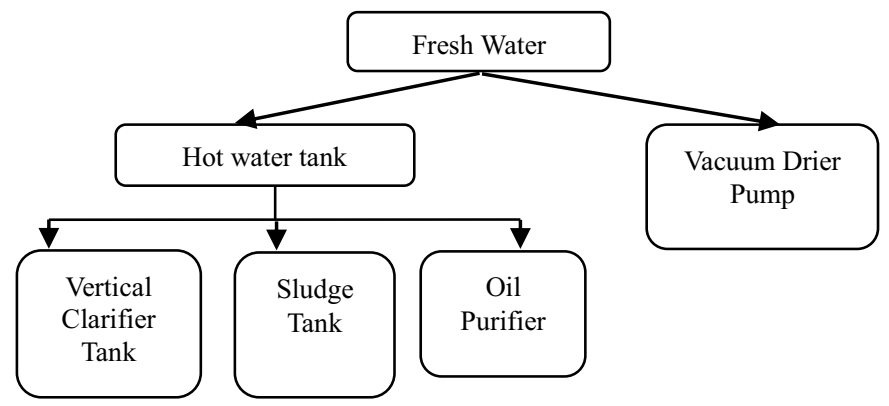

Fig. 2. The process of water use in the clarification station

\subsection{Methodology of Water Footprint for Palm Oil Production}

In general, water footprint of palm oil production in this study focuses on palm oil milling processes. In the palm oil production, the calculation of water footprint component in the industrial stage only includes the components of blue and grey water because the phases mostly use surface water or groundwater. The calculation of blue water in industrial process refers to the amount of water consumed in each stage of production (Hoekstra et al., 2011).

According to Hoekstra et al. (2011), the water footprint of a product can be calculated by using water requirement mechanism in each step of processing product. The calculation of water footprint involves inputs of product, process, product fraction and value fraction (Hoekstra et al., 2011).

The amount of blue water in this stage can be known by calculating the amount of water that is lost through evaporation mechanism at every phase of production. According to Hoekstra et al. (2011), there are difficulties to quantify the amount of evaporation in the production process directly. Therefore, the calculation of water consumption (Consumptive Water Use) for each phase using water balance approach in the industrial stage can be used to calculate the blue water. In analysing this data, a value of product fraction was used. It was a value representing the fraction of water lost during the process in each step in the mill.

Finally the grey water in the industrial stage is an indicator that refers to the pollution of water bodies due to the production activity. Meanwhile, the grey water footprint in the palm 
oil mill was estimated based on data of the volume of waste water having quality lower than the ambient water quality. In determining whether the volume of waste water was calculated or not, data of on-site water quality, effluent quality, ambient of water quality standards, effluent quality standards and the yields were used.

According to Hoekstra et al. (2009), the value of grey water can be assumed to be equal to the amount of the waste if the industry has applied the waste treatment before it is discharged to the environment. As a result, the concentration of pollutants in the effluent has the same value or less than the standard of the ambient water quality value.

The values of water footprints in the mill of palm oil production obtained in this research were then used to represent the existing water use in the palm oil company. Information of existing water use was utilized as the basis for formulating strategies in reducing water footprint in the palm oil company. In formulating the strategies of water reduction in the palm oil company, field notes obtained from the interview were studied and compared with the best practise criteria. In this study, the certified palm oil company, PTP London Sumatra, was identified to get information related to the reduction strategies which have been implemented by the company. The strategies could be the best practise criteria having possibilities to be implemented in the palm oil company based on existing conditions in term of technical and technological, managerial, human resource, and economic aspects.

\section{Results and discussions}

\subsection{Palm Oil Milling Processes in PTP Mitra Ogan}

Figure 3 shows the mass balance of palm oil production in PTP Mitra Ogan milling process.

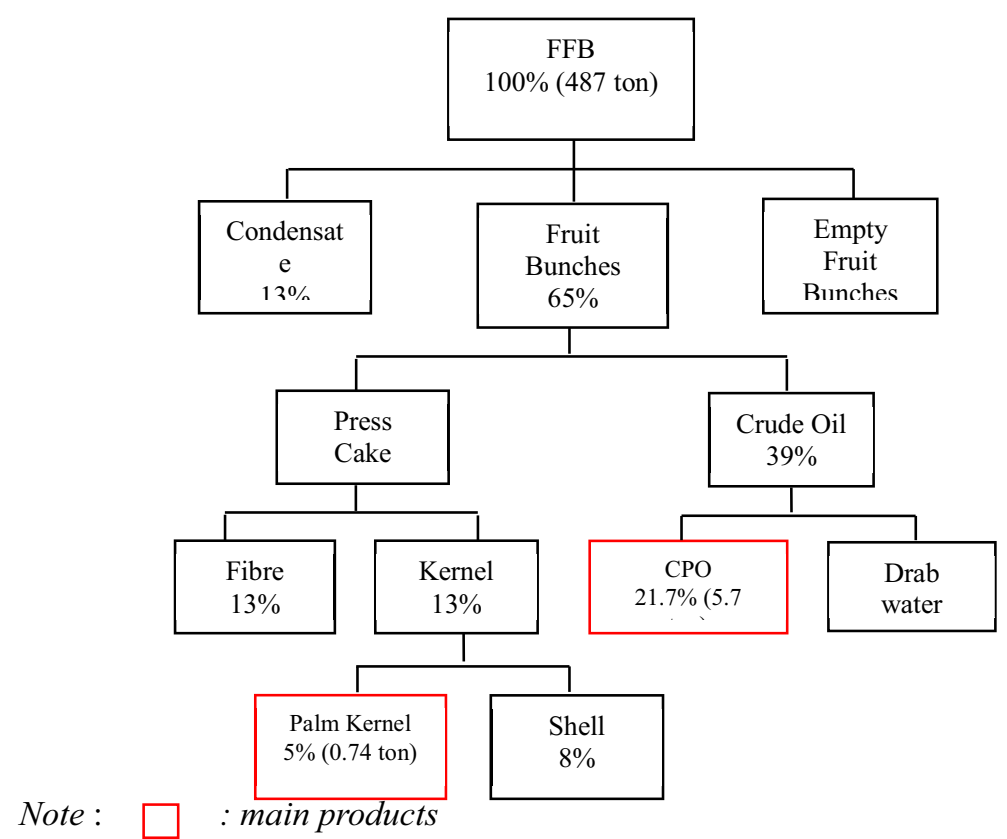

Source: Company Documentation

Fig. 3. Palm Oil Processing in PTP Mitra Ogan 
The average production of FFB produced by the central estate of PTP Mitra Ogan per year is 14.81 tons per hectare. In every hectare of FFB harvested, Crude Palm Oil (CPO) and Palm Kernel produced are about 5.7 ton and 0.74 ton by the mill of PTP Mitra Ogan. With the processing capacity of 30 ton FFB per hour, it can process for about 487 ton of FFB during 22 operating hour in a day.

\subsection{Water Footprint of CPO and Kernel}

\subsubsection{Blue Water Footprint of CPO and Kernel}

Total water use in all stages of the production of CPO and kernel in the PKS unit of PTP Mitra Ogan is $1.36 \mathrm{~m}^{3} /$ ton of FFB. It is equal to $5.08 \mathrm{~m}^{3} /$ ton of production (Table 1). Detailed calculation is presented in Table 5. Based on the average number of processing issued Naibaho (1996: 154) and H-Kittikun et al (2000: 7), the national standard of water use in the PKS unit is equal to 1.1 to $1.2 \mathrm{~m}^{3} /$ ton of FFB. In addition, the amount of blue water in the extraction of $\mathrm{CPO}$ is larger than the value blue water that has been analyzed by Jefferies, et al. (2012), i.e. $2.9 \mathrm{~m}^{3} /$ ton of production. This value shows that there is a wasteful use of water in the processing of palm oil at the study site.

Table 1. The Values Of Blue Water Component For Cpo And Kernel

\begin{tabular}{|c|c|c|c|}
\hline No. & Processes & $\begin{array}{c}\text { Water } \\
\text { Quantity } \\
\left(\mathbf{m}^{\mathbf{3} / \text { ton FFB })}\right.\end{array}$ & $\begin{array}{c}\text { Water } \\
\text { Quantity } \\
\left(\mathbf{m}^{\mathbf{3}} / \mathbf{t o n} \text { Prod }\right)\end{array}$ \\
\hline 1 & Boiler & 0.90 & 3.38 \\
\hline 2 & $\begin{array}{c}\text { Hot water tank (press } \\
\text { station) }\end{array}$ & 0.18 & 0.68 \\
\hline 3 & $\begin{array}{c}\text { Clay bath Mixing } \\
\text { (Kernel Station) }\end{array}$ & 0.01 & 0.043 \\
\hline 5 & $\begin{array}{c}\text { Hot Water Tank } \\
\text { (Clarification Station) }\end{array}$ & 0.11 & 0.35 \\
\hline & $\begin{array}{c}\text { Vacuum Drier Pump } \\
\text { (Clarification Station) }\end{array}$ & 0.15 & 0.55 \\
\hline & Total & 1.36 & 5.08 \\
\hline
\end{tabular}

Hoekstra et al., (2009) stated that generally blue water has no effect or greater impacts on the environment than green water does. Blue water represents the need of water obtained from surface water (river) or groundwater. Blue water used will be "lost" through the process of evapotranspiration, whereas it should be a "reserve" of water resources in the ground or river.

Hence, a more efficient use of water for an industrial process becomes important. In addition to minimizing the impact on the environment, reducing the use of water in the treatment process will also reduce the discharging of waste. This means that efforts to reduce water usage during the process potentially reduce the level of pollution caused by wastewater of palm oil. The implementation of clean production technologies and reuse of wastewater produced can be an alternative in reducing the value of blue water in the palm oil processing.

\subsubsection{Grey Water Footprint of CPO and Kernel}

In processing FFB into palm oil and palm kernel, a palm oil mill has a wastewater treatment plant. Wastewater generated during the production process is treated before it is discharged 
into the environment and meets quality standard (Ceff $=\mathrm{Cmax})$. This means that the value of the grey water footprint component in the production process will be equal to the volume of waste water generated due to the capacity of a water body to assimilate contaminants/ pollutants. The presence of wastewater in a water body changes Cnat into Cmax (Hoekstra et al., 2009).

Based on observations in the study location, the waste water from palm oil extraction in the PTP Mitra Ogan is treated before it is discharged into the environment. So, it was assumed that the concentration of pollutants in the effluent is within the standard of the ambient water quality value. As a result, according to its classification, the grey water footprint of the process is the same as the volume of wastewater generated. Due to the limited access to primary data, the data volume of waste water produced was estimated based on the documentation from preliminary studies in PTP Mitra Ogan done by the Estate Departement of Baturaja.

Liquid waste the PKS unit of PTP Mitra Ogan is one of the by products derived from the condensate of the sterilization process, the water from the clarification process, and hydrocyclone (clay bath) water. Based on these results it is known that in the palm oil extraction process based on the material balance and the secondary data of the company. In one operating day, the PKS unit will produce wastewater of approximately $306.81 \mathrm{~m}^{3} /$ ton. This amount is equivalent to $0.63 \mathrm{~m}^{3} /$ ton of FFB processed or $2.36 \mathrm{~m}^{3} /$ ton of waste per ton of production (Table 2).

Table 2. The Value Of Grey Water Component For Cpo And Kernel

\begin{tabular}{|l|l|l|}
\hline Source of Liquid waste & $\begin{array}{l}\text { Persentage } \\
(\mathbf{\%}) *\end{array}$ & $\begin{array}{l}\text { WFproses,grey } \\
\text { (m3/ton) }\end{array}$ \\
\hline Condensate Water & 13 & 63.31 \\
\hline Clarification Station & 45 & 219.15 \\
\hline Hydrocyclone (Clay Bath) & 5 & 24.35 \\
\hline Total & 63 & 306.81 \\
\hline Average / ton TBS processed & & 0.63 \\
\hline Average/ton production & & 2.36 \\
\hline
\end{tabular}

*Source: Company document

Note: - Total amount of CPO \& kernel produced per day: 130.03 ton

Handling of palm oil waste includes changing complex organic substances into a simple one microbiologically and anaerobically. Biological processes that occur in each treatment pond are: wastewater is collected in effluent ponds, before being released into the water, the water is treated anaerobically in a digester. Generally, waste water treatment plant (WWTP) consists of the following units:

a. Fat pit

Wastewater produced from washing apparatus, condensate sterilizer, sludge separator, and purifier is directly stored in the pit fat ponds. Wastewater in a pit fat sewer can separate oil and water on its density. The top layer of waste is conducted back into the cleaning (clarified) part. Furthermore, waste water containing less oil is conducted into the ponds.

b. Cooling Tower

This cooling tower is used to cool the hot waste water, so that the waste water temperature is lower than $40^{\circ} \mathrm{C}$ for supporting the life of anaerobic bacteria in the next ponds. The towers are arranged in series (sequence). Furthermore, the waste discharged into a seeding pond in which bacteria are bred.

c. Anaerobic Pond 
An anaerobic pond consists of two ponds with a total volume of wastewater of 126.720 $\mathrm{m}^{3}$. Basically, the system used in the multiple feeding is an anaerobic system, namely a system that does not require oxygen in the process of changing organic materials. This change requires anaerobic bacteria to enable this process. After the process in WWTP has been done, waste water is conducted into an area through a piping system designed based on the field conditions.

\subsection{Strategies of Reducing Water Footprint during Milling Process}

During the processing of palm oil in the mill, it is known that it is possible to use water in a smaller amount to obtain the same yields. The amount of blue water footprint of palm oil in the PKS I of PTP Mitra Ogan is $1.36 \mathrm{~m}^{3} /$ ton of FFB. This amount of water indicates an uncontrolled and inefficient water use. Reducing the value of the use of surface water can be done by recycling wastewater as recommended in the manual of Environmental Impact Control Technology Palm Oil Industry (BAPEDAL, 1988 in Fitria 2003).

In addition, based on a comparative study conducted by the researcher to the PKS of PTP London Sumatra (Lonsum) located in Banyuasin, saving water use can be done by using a steam accumulator. However, it requires further study to be applied in PTP Mitra Ogan such as the technical and financial analysis of the company.

\subsubsection{The Use of Steam Accumulator}

Based on a study conducted by the researcher in the PKS of PTP London Sumatra in Banyuasin in August 2014, the use of blue water in the mill can be reduced by the use of steam accumulator. Besides, a research conducted by Shah et al. (2009) has proposed steam accumulator to stabilise the steam pressure fluctuation in palm oil mil especially at the demand sites. However, additionally study needs to be done to ensure the possibility of installing a steam accumulator in the mill in which the size of Back Pressure Vessel (BPV) and the capacity of steam consumed vary.

According to an interview conducted with the manager of mill, the PKS will use a steam accumulator when increasing the production capacity at 45 tonnes of FFB / hour to 60 tons of FFB / hour. Despite an increase in capacity, the amount of steam that flows will remain the same as the initial capacity, so the efficient use of water will automatically happen in the boiler. The steam accumulator is used in order to improve the efficiency of the steam supply from BPV (Back Pressure Vessel) to be conducted into the process. This means that the steam accumulator can save about $40 \%$ of water use by the boiler. However, further study need to be done so that it can be applied properly accordance with the technical, financial and environmental aspects of PTP Mitra Ogan mills.

The work principle of a steam accumulator is when the boiler is supplying steam to the turbine, the remaining steam coming from the turbine is used for other processes in the palm oil mill. This remaining steam is stored in the BPV tank and will be distributed to some of the equipment like sterilizer in the oil mill at a tank pressure of 3 bar (44.1 psi). When the steam consumption is too much, the tank pressure decreases. It causes the process in the sterilizer takes a relatively long time (95 minutes). To save time and water use in the boiler, a steam accumulator is added to improve the quality and efficiency of the supply of steam to the processing areas in the oil mill. In order to maintain tank the BPV pressure at 3 bars, when the pressure of BPV tank is reduced by less than 3 bars, then the valve (PCV-b) will open slowly to supply steam to the BPV tank from the steam accumulator.

Meanwhile, when the pressure of the BPV tank has reached 3 bars, the valve (PCV-b) will close. This process is continuous if there is a change in pressure between the BPV tank and steam accumulator under or above 3 bars. As result, a steam accumulator accelerates 
the process in the sterilizer becoming 40 minutes. The steam accumulator is illustrated in Figure 4.

\subsubsection{Reuse of Condensate Water for Diluting Press and Vibro}

In addition, saving water in processing palm oil can also be done in the pressing station. The reuse of wastewater is done based on the recommendations of the manual of Environmental Impact Control Technology Palm Oil Industry (BAPEDAL, 1988 in Fitria 2003), key informant (machinist head assistant) and the amount of discharged water, as well as previous studies conducted by Fitria (2003) in the POM of Sei Mangkei, North Sumatra. The strategy based on the study in POM of Sei Mangkei can also be applied in PTP Mitra Ogan because both companies have similarities in term of production capacity, production process and the types of machines used. However, further studies which consider the suitability of the financial, technical, and environmental aspects of the company should be done to apply this strategy.

The efficiency is done by maximizing the water condensate in the process of sterilization or TBS boiling. TBS boiling process in the sterilizer produces liquid

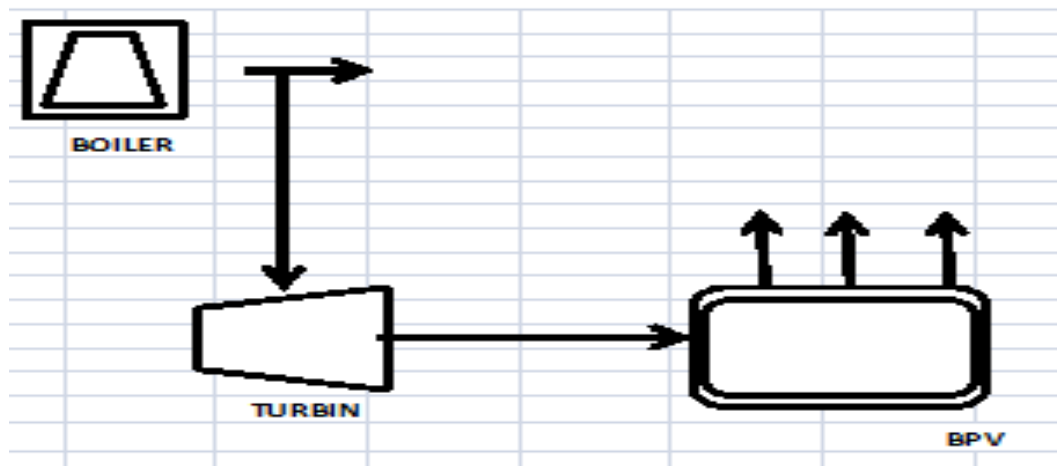

The flow scheme before applying a steam accumulator

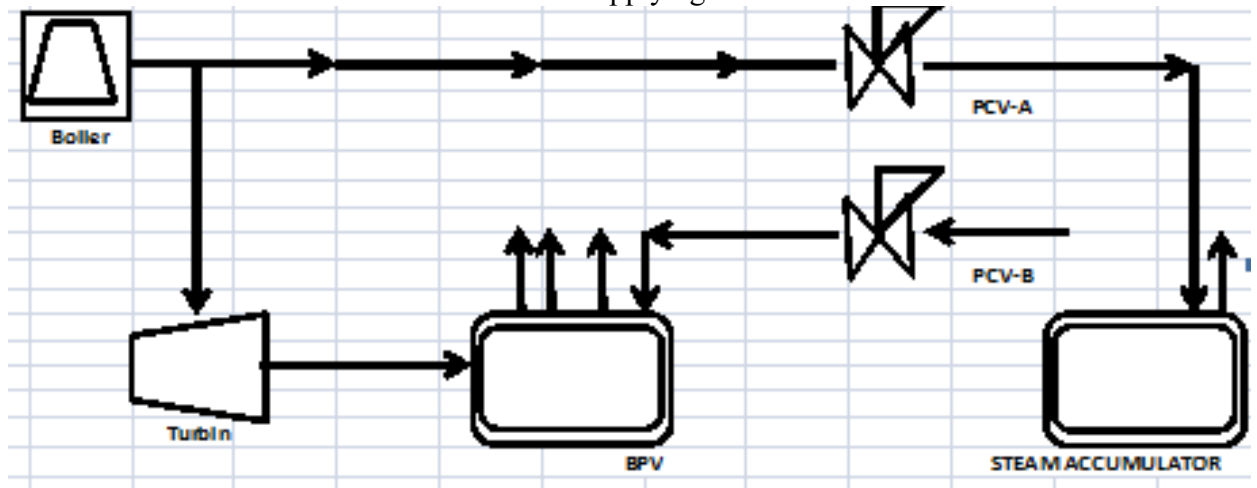

The flow scheme after applying a steam accumulator

Note: $P V C=$ Pressure Valve Control

Fig. 4. The Flow Diagram of Before and After the Application of Steam Accumulator 


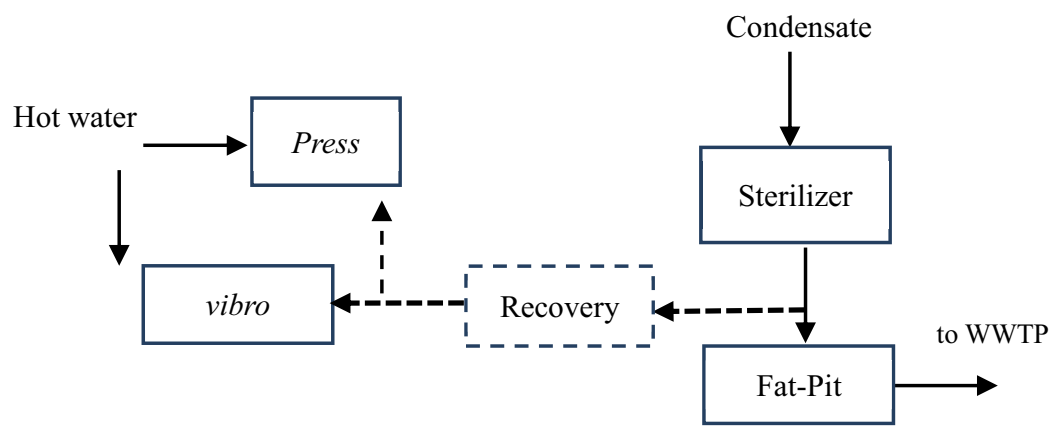

Fig. 5. The flow diagram of Reuse of Condensate Water for Diluting Press and Vibro

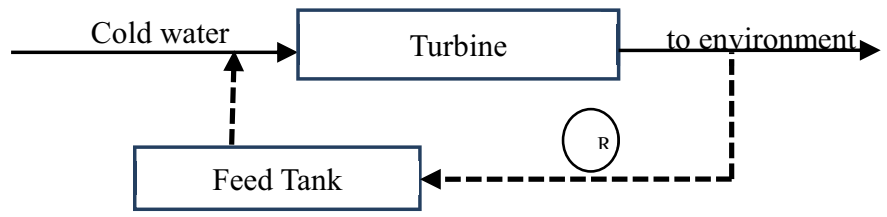

Fig. 6. The Flow Diagram of Recycling of Water from Turbine

waste in the form of condensate generally disposed to the receiver after being processed in the fat pit and WWTP. By considering the demand of water for dilution in the press unit, the temperature for dilluting press is about of $90-95{ }^{\circ} \mathrm{C}$ (Standardization Team of Palm Oil Processing. Directorate General of Estate, 1997 in Fitria, 2003).This aims to facilitate the separation of the oil in the press and clarification units. In addition, the function of hot water is to ease the process of the separation of palm kernel and seed, and maintain the calorific value of fiber (pulp press) as the boiler fuel.

The vibro screen unit acts as the filter for filtering solids from the oil coming from the press unit. In addition to requiring water for diluting oil in the press unit (if the viscosity is too high), water is also required for the dilution process to facilitate the flow of solids (sludge) as a result of the separation of waste that must be disposed. For the purposes, the water used does not require any special requirements, so the use of condensate water can be done.

The use of water as shown in Figure 5 is the process of water recovery from boiled waste water discharged into the water body after being processed in the fat-pit and WWTP. The water will be reused for dilution purposes, extra water (dilution) in the unit of press and a small portion for vibro waste, so that the high polluted wastewater does not negatively affect the environment. A decrease in the use of water by reusing wastewater can reach $10 \%$ where it will affect the amount of wastewater discharged. Approximately $25 \%$ of high polluted wastewater can be reduced by applying this method (Fitria, 2003).

\subsubsection{Recycling of Water from Turbine}

Based on the recommendations of the machinist head assistant, the recycling of water from turbine can also reduce the use of blue water in the mill. The concept of water recycling in Figure 6 is the process of reusing the cooling water coming from the turbine, so the water can be recovered for cooling after being collected in the collector and then returned to the hot well tank for the purposes in the clarification unit. Water as much as $0.20 \mathrm{~m}^{3} /$ ton of FFB is directly discharged into the environment during this process. Figure 6 illustrates that 
the water used for cooling the turbine that is low pollutant can be reused without any special treatments. The water is then collected in a collector tub for being reused. Based on the results of a research conducted by Fitria (2013) in the POM of Sei Mangkei, North Sumatra, reusing (recycling) water for cooling turbine can reduce water consumption by $16 \%$ accompanied by a decrease in the discharge of liquid waste by $100 \%$, which is low pollutant. Based on the analysis, POM of Sei Mangkei uses similar specification of turbine and has similar power plant production flow, so it is assumed that it is also applicable in PTP Mitra Ogan.

For saving time of using water for cooling the turbine, a cooling tower can also be used in which a fan that will speed up the cooling process in the turbine. Decision making in using water efficiently depends on the costs, technical and environmental considerations of the mill.

\section{CONCLUSIONS}

The average value of palm oil water footprint in PTP Mitra Ogan showed that there is an inefficient use of water. The increase use of the blue water, the potential contamination by the waste of palm oil will be larger, so that reducing strategy of the water footprint is very crucial. Waste water reuse strategies and application of clean technology are expected to minimize the inefficient use of water by the company, which will reduce the amount of liquid waste.

However, additionally study based on more exact data is required in the assessment of the water use impacts because there were not enough detailed and specific data available in this research. Besides, further studies in quantifying the affectivity and efficiency aspects of the strategies proposed are also required to be done.

The authors are grateful to Beasiswa Unggulan Scholarship Indonesia and University of Twente Scholarship, Leeuwarden, Netherland, for supporting this work and to PTP Mitra Ogan and PTP Lonsum, South Sumatra, Indonesia, for making data available.

\section{REFERENCES}

1. L.D. Bergert, (Thesis Master, Michigan Technology University 2000)

2. A.K. Chapaign, D. Ticker, Water Footprint: Help and Hidrance in Water Alternatives, 5(3), 565 (2012)

3. A. Fitria, (Thesis Master, Universitas of Indonesia 2003)

4. A.H. Kittikun, Environmental Management for Palm Oil Mill. Integreted Bio-system Network. Tokyo. 12 (2000). http : www.ias.unu.edu/proceeding/icibs/ic.unfal.index.

5. Hoekstra et al., 2009. Water Footprint Manual: State of the Art. Netherland: Water Footprint Network (2009). Available online at: www.waterfootprint.org. Accessed on April $19^{\text {th }}, 2014$.

6. Hoekstra, A.Y., A.K. Chapagain, M.M. Aldaya, M.M. Mekonnen. The Water footprint Assessment Manual : Setting the Global Standard. London: Earthscan (2011). Media release: (http://www.waterfootprint.org).

7. A.Y. Hoekstra, A.K. Chapagain, M.M. Aldaya, M.M. Mekonnen, Water footprint manual: State of the art (2009)

8. D. Jefferies, I. Munoz, J. Hodges, V.J. King, M. Aldaya, A.E. Ercin, L.M. Canals, A.Y. Hoekstra, J. Clean. Prod., 32, 155 (2012)

9. S.A. Muyibi, T. Tajari, M.S. Jami, M.K. Amosa, Adv. Environ. Biol., 590 (2014)

10. M.P. Naibaho, Teknik Pengolahan Kelapa Sawit Pusat Penelitian Kelapa Sawit, Medan, 306 (1996) 
11. I. Pahan, Panduan Lengkap Kelapa Sawit, Bogor, Penebar Swadaya (2006)

12. Sappi, (Sustainable Palm Oil: Conversation and Debate 2013)

13. Sappi, Water Use and Treatment in the Pulp and Paper Industry. Boston: Fine Paper North America vol.5 (2012).

14. Stockholm Environment Institute (SEI), (2012)

15. M.H.S. Ismail, A. Aziz, M. Kamal, N.A. Morad, Eur. J. Sci. Res., 37(4), 628 (2009)

16. World Wild Fund (WWF). Palm Oil: Minimizing Water Use (2013). Available online at: wwf.panda.org. Accessed on April 17 $7^{\text {th }}, 2014$. 